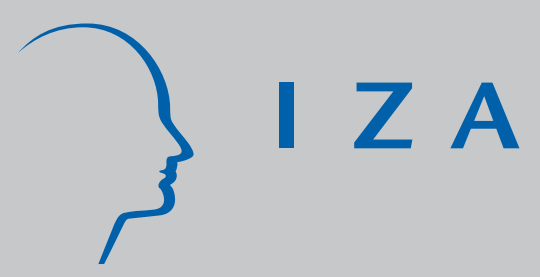

IZA DP No. 3811

An Experimental Study of Sex Segregation in the Swedish Labour Market: Is Discrimination the Explanation?

Magnus Carlsson

Dan-Olof Rooth

November 2008 


\title{
An Experimental Study of Sex Segregation in the Swedish Labour Market: Is Discrimination the Explanation?
}

\author{
Magnus Carlsson \\ Kalmar University \\ Dan-Olof Rooth \\ Kalmar University \\ and IZA
}

Discussion Paper No. 3811

November 2008

\author{
IZA \\ P.O. Box 7240 \\ 53072 Bonn \\ Germany \\ Phone: +49-228-3894-0 \\ Fax: +49-228-3894-180 \\ E-mail: iza@iza.org
}

\begin{abstract}
Any opinions expressed here are those of the author(s) and not those of IZA. Research published in this series may include views on policy, but the institute itself takes no institutional policy positions.

The Institute for the Study of Labor (IZA) in Bonn is a local and virtual international research center and a place of communication between science, politics and business. IZA is an independent nonprofit organization supported by Deutsche Post World Net. The center is associated with the University of Bonn and offers a stimulating research environment through its international network, workshops and conferences, data service, project support, research visits and doctoral program. IZA engages in (i) original and internationally competitive research in all fields of labor economics, (ii) development of policy concepts, and (iii) dissemination of research results and concepts to the interested public.
\end{abstract}

IZA Discussion Papers often represent preliminary work and are circulated to encourage discussion. Citation of such a paper should account for its provisional character. A revised version may be available directly from the author. 
IZA Discussion Paper No. 3811

November 2008

\section{ABSTRACT}

\section{An Experimental Study of Sex Segregation in the Swedish Labour Market: Is Discrimination the Explanation?*}

This paper studies whether sex discrimination is the cause of sex segregation in the Swedish labour market. The correspondence testing (CT) method was used, which entails two qualitatively identical applications, one with a female name and one with a male name, being sent to employers advertising for labour. The results show that females have a somewhat higher callback rate to interview in female-dominated occupations, while in male-dominated occupations there is no evidence of any difference. The conclusion is that the sex segregation prevailing in the Swedish labour market cannot be explained by discrimination in hiring. Instead, the explanation must be found on the supply side.

JEL Classification: J64, J71

Keywords: $\quad$ sex discrimination, segregation, exit from unemployment

Corresponding author:

Magnus Carlsson

Baltic Business School

Kalmar University

39182 Kalmar

Sweden

E-mail: magnus.carlsson@hik.se

\footnotetext{
* We would like to thank Jan Ekberg, participants at seminars at Växjö University, the Institute for Labour Market Policy Evaluation and Lund University, as well as participants at the 2007 ESPE Conference in Chicago and the 2007 EALE Conference in Oslo for their valuable comments. Klara Johansson provided excellent research assistance. A research grant from the Swedish Council for Working Life and Social Research is gratefully acknowledged.
} 


\section{Introduction}

The employment rate for females in the Swedish labour market is among the highest in the world. ${ }^{1}$ However, from an international perspective the Swedish labour market is also highly segregated based on sex (le Grand, 1997; Löfström, 2005). ${ }^{2}$ Occupational segregation between the sexes is in fact greater than the segregation between natives and immigrants (Ekberg and Rooth, 2004). Females tend to work in healthcare, education and the detail trade, whereas typical male jobs are engineering, construction work and truck driving. ${ }^{3}$ Interestingly, occupational segregation explains a significant part of the non-adjusted sex wage gap in Sweden, which is about 16 percent. ${ }^{4}$ Wages are on average lower for both males and females in occupations with a high share of females, and higher in occupations with a low share of females. Two important questions arise: 1) why is the labour market segregated with respect to sex, and 2) why are female jobs paid less?

This study deals with the first question by studying a factor that potentially supports the prevalent segregation, namely the existence of sex discrimination in employment. 5 To measure the existence of sex discrimination, the correspondence testing (henceforth CT) method is used. Internationally, various forms of field experiments such as CT have become an increasingly common method for demonstrating both ethnic and sex discrimination (Riach and Rich, 2002; 2006). CT entails the researcher submitting qualitatively identical written job applications for actual advertised vacancies. The name assigned to the applications is the only difference, and reflect in this case the sex of the individual - one female and one male name. Each sent resumé is then recorded in terms of whether or not the applicant is invited to interview. The procedure is repeated for a sufficient number of vacancies in order to obtain a representative result. If the callback rates for the male and female applicant are significantly different, it must be due to sex discrimination

\footnotetext{
172.1 percent of women 16-64 years old were employed in 2006 (Labour Force Survey, Statistics Sweden, 2006).

${ }^{2}$ In this article, segregation is simply defined as the share of females. An occupation is not segregated if 50 percent of the employees are males/females. An occupation is completely segregated if 0 or 100 percent of the employees are males/females.

3 Statistics Sweden, 2006.

${ }^{4}$ Statistics Sweden, 2006.

${ }^{5}$ In this article, employer discrimination is defined as occurring when two individuals are treated unequally in a hiring situation, even though their productive characteristics observed by the employer are identical.
} 
since CT ensures that all individual productive characteristics are controlled for, something that is usually hard to accomplish using register data analysis.

The degree of sex discrimination in 13 different occupations is analysed, including male-dominated, mixed and female-dominated jobs, making it possible to analyse its relationship with segregation. Finally, the characteristics of discriminating employers are examined. The results reveal that females have a somewhat higher callback rate in female-dominated and mixed occupations compared to males. In male-dominated occupations there is, perhaps surprisingly, no evidence of any differences in the probability of being invited to interview. Some simple calculations show that the slight difference in callback rate cannot explain the substantial sex segregation prevailing in the Swedish labour market. The conclusion is that the driving force must be found on the supply side.

Focusing on the firm level, there are still individual employers treating the applicants differently. Using this variation to analyse the characteristics of employers shows that on the firm level neither the sex composition of employees nor the sex of the recruiter influence the difference in callback rate between the applicants. Further, public sector employers are, perhaps surprisingly, less likely to invite female applicants than males.

The next section presents an overview of some existing theories explaining discrimination and segregation in the labour market. Section 3 describes the method, Section 4 summarises previous research, and Section 5 discusses data gathering and presents the descriptive results. Section 6 presents the empirical analysis, and interpretations and conclusions are presented in Sections 7 and 8.

\section{Segregation and discrimination}

Sociologists and economists have proposed various theories to explain sex segregation in the labour market. On the demand side it is the existence of discrimination that can lead to segregation. ${ }^{6}$ Sociologists explain discrimination as

\footnotetext{
${ }^{6}$ The supply side can also affect the degree of segregation (this is kept constant in this experiment). On the supply side, sociologists' and economists' explanations also differ. The simplest sociological explanation is that individuals are socialised to an idea of female and male jobs when growing up (England, 2005). Classical economists, on the other hand, maintain that individuals strive towards maximising lifetime income, and that women are more likely to wish to combine work and family life (Polachek, 1981; 1985).
} 
employers having a socially constructed image of what constitutes male and female jobs (England, 2005). This view is probably in line with what economists call statistical discrimination. This implies that employers expect a male to be more productive in occupations viewed as male jobs and females to be more productive in occupations viewed as female jobs (Phelps, 1972; Arrow, 1973). This is the first type of statistical discrimination where employers classify individuals on the basis of group belonging, following the qualification of the average member of that group instead of the qualifications of the individual. The second type of statistical discrimination implies that members of a group are discriminated against because employers view their productivity with different accuracy. In the case of sex discrimination it may not be obvious why employers would observe male and female productivity with different precision.

The other main type of economic discrimination is Beckerian employer, coworker and customer discrimination (Becker, 1957). Based on this theory, employers are against employing individuals from a certain group because of their negative preferences. Discrimination can therefore occur even if there are no differences in average productivity or productivity variance. In a similar way, co-workers can have objections to work and customers can be against engaging in transactions with members of a certain group. In some cases these theories predict a segregated labour market. ${ }^{7}$

\section{Method}

Estimating the degree of sex discrimination in the labour market is an often demanding task. If the analysis is based on register data, one can rarely exclude the existence of variables that are unobserved by the researcher but observed by the employer. If such unobservable variables are present and also correlated with the individual's sex, the estimated parameter of discrimination will be biased.

To make inferences about discrimination from interview data is also problematic. Job seekers may overstate or understate the degree of discrimination, and employers won't necessarily communicate their true attitudes about certain

\footnotetext{
${ }^{7}$ For a detailed discussion of the different cases when segregation is predicted, see Altonji and Blank (1999).
} 
groups, and even if they do so, attitudes are not automatically consistent with behaviour.

The main advantage with the CT method is that it ensures that the researcher observes exactly the same variables as the employers. This is guaranteed by the construction of the experiment, where qualitatively identical applications are sent to employers advertising for labour. The only difference between the applications is the names of the candidates, which are carefully chosen to signal being either male or female. Having sent the resumés, the number of invitations to interview is calculated for each applicant. If a significant difference between the candidates is found, it must be the case that employers use the name of the candidates as a decision variable - in other words, discrimination is observed.

One criticism of $\mathrm{CT}$ is that the results cannot be regarded as representative of the labour market as a whole (Allosino et al., 2004). The reason is that in CT only a limited number of occupations are studied during a specific period of time. Further, jobs are usually only applied for via formal methods (job advertisements), whereas in real life a considerable number of job offers are obtained via informal search methods and networks (Segendorf and Rooth, 2006). However, such criticism applies to experimental methods in general and not just CT, since experimental methods are often restricted to study subsets of whole populations.

A further criticism is that if a candidate is not invited to interview, it is not known whether the candidate would have got the job if an interview had taken place. Regarding unequal treatment with respect to ethnicity, about 90 percent of all unequal treatment occurs in the stage of being called to an interview (Riach and Rich, 2002, and own calculations). Regarding sex discrimination, it has not been possible to carry out a similar calculation as a result of a lack of data, but it seems reasonable to assume that most unequal treatment takes place at the interview stage. If the applicant's sex matters in the hiring decision it is probably most efficient to carry out the selection at an early stage in the recruitment process.

\section{Previous research using CT}

In Europe, Australia and the US, several studies of sex discrimination in employment have been conducted by applying the CT method. (see Table 1). 
However, as far as we know, none of them links the results to sex segregation in a systematic way. In Sweden, CT has not been used at all to measure sex discrimination. ${ }^{8}$

Riach and Rich (1987) used written matching applications to study sex discrimination in Victoria/Australia in hiring accountants, computer professionals, gardeners, and industrial relations officers. In the male-dominated occupation of gardening, males had a callback rate that was 25 percentage points higher. In the other occupations, non-significant differences were found (see Table 1).

Neumark et al. (1996) studied discrimination in restaurants in Philadelphia/US. The experiment included two stages: the interview stage (similar to CT), which determined whether the candidates were called to an interview or not, and the job offer stage (audit testing), where real people attended an interview. Matching pairs, consisting of one female and one male, applied for jobs as waitresses/waiters in restaurants of three different price classes - high, medium and low. Unlike in other studies, jobs were also applied for at restaurants that had not advertised for labour (so-called blind applications). They found that females were discriminated against in the high-price restaurant category, and males tended to be discriminated against in the low-priced restaurants (see Table 1). One interpretation is that preference-based customer discrimination exists, such that customers prefer a male waiter in more luxury restaurants and a female waitress in simpler restaurants, which was taken into account by the recruiter.

Weichselbaumer (2004) conducted a CT in Vienna/Austria by sending written applications to employers that posted vacancy ads in daily papers. She tried to emphasise personality in the applications with the aim of influencing sex stereotypes, and thus identifying preference-based discrimination from statistical discrimination. Three applications were sent, one male and two female. The personality of one female was made more masculine, and the other was more traditionally feminine, based on what Weichselbaumer (2004) maintained as typical male and female qualities. On the basis of this construction, she argued that the masculine female signalled the qualities that are considered to be important in male-dominated occupations. The hypothesis was that if employers in male-

8 There is, however, a quasi-experiment (Edin and Lagerström, 2006) 
dominated occupations discriminated less against the masculine female than against the feminine one, it was a result of less statistical discrimination. However, the results do not show any significant differences in discrimination vis-à-vis the masculine female and feminine female.

Weichselbaumer's (2004) interpretation of these results is that sex discrimination is an effect of preferences, and that sex per se and not productiverelevant personality drives labour market discrimination. However, such an interpretation requires the applications to contain complete information about all relevant productive characteristics, otherwise the employer may still use sex stereotypes to predict missing information, hence statistical discrimination may be present in any case. Regardless of the type of discrimination observed, Weichselbaumer (2004) found that females were discriminated against in the maledominated occupation of computer specialists, and males were discriminated against in the female-dominated occupations of accountants and secretaries (see Table 1).

Riach and Rich (2006) sent matching pairs of written applications to employers in London/UK who advertised vacancies in daily papers and on the Internet. Four different occupational categories were investigated. They found that males were discriminated against in the female-dominated secretarial occupation, and females were discriminated against in the male-dominated engineering occupation. For the mixed occupations of accountants and computer professionals, males were found to be at a disadvantage (see Table 1).

$* * *$ Table 1 here $* * *$

\section{Data gathering and results}

This section describes the motivation for the choice of occupations analysed in the experiment and the construction of the applications, explains how the data were gathered, and provides descriptive results.

\subsection{Occupations and geographical regions}

To test whether sex discrimination exists and maintains sex segregation in the labour market, it is necessary to study both female- and male-dominated 
occupations. It is also interesting to compare the degree of sex discrimination in occupations with different qualification levels and in both the private and public sectors. In addition, to achieve reasonable progress in the collection of observations, the demand for labour has to be sufficiently high in the included occupations.

The following 13 occupations fulfilled the research requirements: computer professionals, motor-vehicle drivers, construction workers, business sales assistants, teachers (preschool, lower secondary school language and maths/science, and upper secondary school), restaurant workers, accountants, cleaners, shop sales assistants, and nurses.

For practical reasons, data collection was restricted to the two major cities of Sweden: Stockholm and Gothenburg. ${ }^{9}$ For instance, it was necessary to subscribe to phone lines with automatic answering machines and allocate real postal addresses for the applicants, making it possible for employers to establish contact. Two separate phone lines were needed for each region and area code, one for each applicant, placing limits upon the number of regions that could be studied. Access to real postal addresses was also limited, with reliance upon borrowed $\mathrm{C} / \mathrm{O}$ addresses in each region for the two applicants.

\subsection{The applications}

The applications consisted of a brief personal letter on one page and a CV on another page, and were constructed to be realistic even though they did not describe an existing person. As considerable competition from other job seekers was expected, the applicants had to be well qualified.

For each occupation, about 20 resumés belonging to real persons available at the homepage of the Swedish Employment Service were used as templates. These applications were combined and colleagues at Kalmar University were consulted regarding whether they recognised any qualitative differences. If they did, the applications were adjusted and recalibrated, and the iterative process continued until no qualitative differences were perceived (see Appendix B for example resumés). Finally, three standardised applications for each occupation were obtained stating identical qualifications but with a somewhat different typeface and layout to

\footnotetext{
9 The experiment was also started in Malmö, the third largest city in Sweden, but there were not enough jobs available to make progress.
} 
avoid raising suspicion. A post ex sensitivity analysis shows that there was no difference in the probability of being invited to interview for different applications.

The choice of the individuals' names was vital, since the name was used to signal the sex of the applicant. The most frequently found female first names, male first names and last names in Sweden were chosen. ${ }^{10}$

Relatively young individuals who had recently entered the labour market were studied for two main reasons. First, sex discrimination is often discussed in the context of pregnancy and childcare. One hypothesis is that females are discriminated against because they are more likely to quit work due to pregnancy and childcare, disrupting their employment. Therefore, it is interesting to study individuals at an age where they are likely to raise a family. Second, it would be very demanding to create convincing applications for older candidates covering a whole working life. The age of the applicants was therefore set to 24-29 years old, depending on the required education and work experience for the particular profession. The amount of work experience given in each occupation was two to five years, based on the expected competition from other job seekers.

The job openings were collected from the Swedish Employment Agency's homepage, the site in Sweden where most vacancies are found. ${ }^{11}$ Only employers accepting applications sent by email were included in the experiment, which constitutes the majority of employers in Sweden.

The procedure to apply for a job was to randomly pick a male and a female name from the pool of names and then make a random choice of two applications for each candidate. Relevant contact information was then attached, consisting of a telephone number (with an automatic answering machine), an email address registered at a large Internet provider, and a real postal address always referring to similar neighbourhoods. However, none of the employers invited any of the applicants via regular mail. To avoid giving any of the candidates the systematic advantage of having his/her application being sent first, the order was alternated.

\footnotetext{
10 For males, the first names Erik, Karl and Lars and the last names Andersson, Pettersson and Nilsson were used. For women, the first names Eva, Anna and Maria and the last names Karlsson, Eriksson and Johansson were used. These are the most common names according to Statistics Sweden (2006). Sensitivity analysis shows that different names (within sex) had no statistically significant effect upon the probability of being called to an interview.

11 By law, employers have to report vacancies to the Employer Agency. The law is not enforced, but most vacancies are still found there.
} 
The applications were usually sent with one day's delay, and to minimise the inconvenience for employers, all interview offers were immediately declined.

\subsection{Firm/workplace and recruiter information}

By collecting information about the firms participating in the experiment it was possible to analyse the distinguishing characteristics of firms that treat the applicants differently. The sex of the recruiter was obtained from the job ads. It was also possible to identify the workplaces in Statistics Sweden's business register using workplace IDs (so-called CFAR-no, see www.scb.se). ${ }^{12}$ From the registers, information was obtained on the share of male employees at the firm, the number of employees at the workplace and the firm as a whole (if more than one workplace), the number of workplaces of the firm, and whether it is a public sector employer or not. ${ }^{13}$

Analysing how these variables relate to unequal treatment is interesting in several ways. For example, information on the sex of the recruiter and the share of males at the firm may indicate the role that segregation plays in discrimination at the firm level and what type of discrimination is observed. For example, suppose that discrimination is present, if preferences are the source it is expected by definition that the treatment of males/females changes with the sex of the recruiter and the share of male/female employees. If this is not the case, only statistical discrimination is left as an explanation of unequal treatment.

The number of employees at the firm can also reveal whether unequal treatment is linked to such things as the experience of hiring staff. Finally, in light of the political debate in Sweden about equal opportunities in the labour market, it is interesting to analyse whether public sector employers treat the applicants more equally compared to private employers.

\subsection{Descriptive results}

\footnotetext{
12 Company IDs were identified from combining information on firm name and address found in the job ad with information in Statistics Sweden's business register available on the Internet.

${ }^{13}$ In 63 percent of the cases the firm only has one workplace, hence firm and workplace form the same unit.
} 
Table 2 shows the aggregate results for the Stockholm and Gothenburg regions. ${ }^{14}$ It demonstrates that a total of 3,228 applications were sent to 1,614 job openings. The four possible outcomes in CT are neither applicant invited, both invited, only the male applicant invited, and only the female applicant invited. From the first row it can be read that in 982 cases neither individual was invited to an interview, while in 632 cases at least one was. In 336 cases both individuals were invited, in 125 cases it was only the male, and in 171 cases it was only the female. The callback rates for the male and female applicant are 0.29 and 0.31 respectively. The last column shows that the difference in callback rate is approximately two percentage points at the mean. However, this result does not necessarily apply to the labour market in general since more female-dominated occupations were included in the experiment. Instead, dividing the occupations based on the share of males/females allows the analysis to be linked to segregation.

The remaining rows in the table show the result for each occupation, being ordered by the share of males/females in the occupation. Male-dominated occupations are defined as those with more than $2 / 3$ males, mixed occupations as those having between $1 / 3$ and 2/3 males, and finally, female-dominated occupations as those with less than 1/3 males (information taken from Statistics Sweden, 2006). Male-dominated occupations include computer professionals, motor-vehicle drivers and construction workers; the total number of jobs applied for of this type was 248 . The callback rate is on average four percentage points higher for males compared to females among these occupations. Mixed occupations comprise business sales assistants, lower secondary school teachers (language), and upper secondary school teachers. The mean result for this group is that the callback rate for males is four percentage points lower compared to females. The occupations categorised as femaledominated include restaurant workers, accountants, cleaners, preschool teachers, shop sales assistants, lower secondary school teachers (maths/science), and nurses. The callback rate for males for the group as a whole is four percentage points lower than for females. The discussion of the results by occupation follows in the next section.

\footnotetext{
14 The relative callback rates do not differ significantly between Stockholm and Gothenburg. Therefore, only the aggregate result is presented.
} 


\section{Empirical analysis}

In this section, the differences in the probability of being invited to interview for the male and female applicants are analysed using all 3,228 applications and 1,614 workplaces. The goal is to study whether females and males have different probabilities of being invited depending on the occupation, and the share of females in the occupation. Thereafter it is estimated which, if any, workplace and recruiter characteristics influence these differences using the 2,996 applications and 1,498 workplaces identified in the registers. ${ }^{15}$ Of particular interest is whether the share of females at the firm and the sex of the recruiter have an impact on explaining sex differences in the probability of being invited to interview.

\subsection{Sex differences in invitation probability}

Three different probit models were used to analyse the probability of being invited to interview for males and females, all with the callback dummy as the dependent variable reporting the effect of discrete changes in the explaining dummy variables.

Model 1 in Table 3 regresses the callback dummy on the female dummy alone. As can be seen, having a female name increases the probability of being invited to interview by an average three percentage points (significant at the one percent level).

Model 2 regresses the callback indicator on the category variables of maledominated, mixed or female-dominated occupation (where the male-dominated occupation is the benchmark). The category variables are also interacted with the female dummy to reveal any differences in the probability of being invited to interview between sexes within the three groups of occupations. From the second column of Model 2 it can be read that in male-dominated occupations, the effect on the probability of being invited to interview of having a female name is negative but insignificant. In mixed occupations, on the other hand, having a female name increases the probability of being invited to interview by four percentage points

\footnotetext{
${ }^{15}$ Hence, 93 percent of the workplaces were identified in the registers.
} 
(significant at the 10 percent level). In female-dominated occupations, the impact is positive and an average four percentage points (significant at the one percent level).

$* * *$ Table 3 here $* * *$

The next model reports the corresponding effects estimated at the occupational level. For a person with a male name it is evident that the probability of being invited to interview varies across occupations (first column of Model 3). The lowest probability is found for cleaners (17 percentage points less than for computer professionals) and the highest for preschool teachers (40 percentage points higher than for computer professionals). From the second column of Model 3 it is clear that having a female name significantly increases the probability of being invited to interview for the following occupations: business sales assistants (six percentage points), restaurant workers (20 percentage points), accountants (12 percentage points), and preschool teachers (six percentage points). For the remaining occupations, the estimated differences in invitation probability between the sexes are insignificant.

To further explore the link between the difference in callback rate and the share of females in the occupation, the correlation coefficient between the two is estimated. If unequal treatment is an important variable in explaining segregation, one would expect to find a negative correlation, that is, a greater difference between the callback rate for the male and female applicant in occupations where the share of females is lower. Table A1 reports the difference in callback rate and the share of females for each occupation. ${ }^{16}$ The correlation coefficient carries the negative sign, but it is statistically insignificant different from zero. Hence, there is no statistical evidence that the difference in callback rate is correlated with the share of females in the occupation.

To sum up the analysis so far, on average, in male-dominated, mixed and female-dominated occupations, the difference in callback rate between the sexes is small. Somewhat larger differences are found in particular occupations, especially

16 The share of females in each occupation is taken from Statistics Sweden (2006). Table A1 also contains the occupational classification with respect to skill. No significant relationship was found between the difference in callback rate and the classification. The occupational classification is a simplification of the Swedish Standard Classification of Occupations (Statistics Sweden, 2006) 
female-dominated occupations where the female candidate has a higher probability of being invited to interview in some cases. In none of the occupations does the male applicant have a significantly higher callback rate. No correlation is found between the difference in callback rate and the share of females in the occupation.

\subsection{Factors influencing the probability of being invited}

Even if the differences in callback rate between males and females on the occupational level are small in most cases, there still exists variation in how the applicants are treated at the firm level, which is utilized in this section. The relevant variables to analyse, where data are available, are the sex of the recruiting person, the share of male employees at the firm, the number of employees at the workplace, and whether the firm is a public or private sector employer (see Table A2 for descriptive statistics).

To investigate which, if any, of the attributes influence the difference in callback rate between the two applicants, the callback dummy is now regressed on the workplace/recruiter characteristics and the interaction of the variables with the female dummy. The extent to which a variable is associated with a difference in callback rate is given by the interaction effect. ${ }^{17}$

In a similar way to the descriptive results, the data are divided into maledominated, mixed and female-dominated occupations in order to allow for a heterogeneous impact of the variables in the three categories. ${ }^{18}$ The first model is estimated on all observations in male-dominated occupations without controls for occupation and firm size. No marginal effects are significantly different from zero. The estimated impact of being a public sector employer is, however, large and negative. Model 2 repeats the analysis but adds occupational and firm size fixed effects. Most estimates are similar to before, but there is a tendency for females to have a higher probability of being invited to interview if the recruiter is male, which might be the opposite of what is expected.

\footnotetext{
17 These are the estimated marginal changes in probability for the continuous variables and estimated discrete changes for dummy variables. For convenience, both are referred to simply as marginal effects.

18 The models have also been estimated for separate occupations and for the whole data set, but no further significant results were found.
} 
In mixed occupations, public sector employers are associated with a lower probability for females of being invited to interview. In Model 3, the effect of the interaction of the public sector and the female dummy is estimated as significant at the five percent level. The absolute value of the point estimate is even higher with fixed effects controls included (Model 4), but the precision is lower. From the estimates of Model 4 it can also be seen that employers with less than 20 employees are associated with a significantly lower probability of females being invited to interview compared to males.

In female-dominated occupations, the probability of female applicants being invited to interview by public sector employers is lower than male applicants. The marginal effect is significant at the five percent level both between and within occupations (Models 5 and 6). The estimates of Model 5 reveal also that the share of males at the firm is significantly associated with differences in the probability of being invited to interview for males and females. A one percent increase in the share of males is associated with, perhaps surprisingly, a 16 percentage point higher probability of being invited to interview for the female as opposed to the male applicant.

\section{Interpretations}

If the hypothesis that sex discrimination is an important factor in explaining sex segregation in the labour market is true, it is expected that females have a lower probability of being invited to interview in male-dominated occupations, and vice versa. In general, very weak support for the hypothesis is found. First of all, the correlation coefficient between the difference in callback rate between males and females and the share of females in the occupation is not significantly different from zero. Moreover, in male-dominated occupations, no evidence is found of females and males having different probability of being invited to interview. In female-dominated occupations, females have on average four percentage point higher callback rate compared to males. In these occupations, a substantial majority of employees are 
females, the share varying from 68 percent for restaurant workers to 92 percent for preschool teachers (see Table A1). But can the four percentage point higher callback rate for females really explain the considerable female dominance in these occupations?

The answer is clearly no and can be illustrated by a simple "back of the envelope" calculation. Assume, as in CT, that females and males supply an identical type and amount of labour and, as is found in this experiment, that females have a 30 percent and males a 26 percent callback rate to interview. Assume also that the share of vacancies that are filled by females and males is proportional to their relative callback rate to interview. This is a reasonable approximation if most unequal treatment occurs when applicants are chosen for the interview stage and not when the interview actually takes place. Then it follows that the share of vacancies that are filled with females is $15\left(\approx \frac{30}{26}-1\right)$ percent higher compared to the share that is filled with males, since the female callback rate is 15 percent higher than the male callback rate. Consequently, out of 100 vacancies, approximately 54 are filled by females and approximately 46 are filled by males ( 54 being 15 percent higher than 46). Suppose also that no discrimination occurs in firing, and that who quits a job is random.

Under these assumptions, eventually the share of females in the sector will be 54 percent and the share of males 46 percent. This is a much lower degree of segregation than is observed in reality. The obvious conclusion is that such a small difference in callback rate of four percentage points cannot explain the segregation that exists in female-dominated occupations. ${ }^{19}$ Consequently, since the demand side cannot explain segregation, the supply side must.

However, if discrimination cannot explain segregation in female-dominated occupations, it may still explain segregation in some particular occupations. What about restaurant workers and accountants, where the largest statistically significant difference in callback rates are found? For restaurant workers the callback rate is 19 percent for females and eight percent for males. When a similar calculation as before is performed, it follows that the share of females would be 70 percent due to the

19 If discrimination was more prevalent in the past it may still explain segregation today. In the long run, however, that effect cannot persist. 
difference in callback rate. Thus, in this case, discrimination alone can explain sex segregation since the share of females in reality is 68 percent. Turning to the accountants, the share of females that is predicted by the difference in callback rates is 62 percent compared to the observed share of 75 percent. In this occupation, discrimination can also explain segregation to some extent.

A somewhat different callback rate for females and males is also found in mixed occupations. This result cannot be explained by some occupations being female jobs and others being male jobs. Can the explanation instead be an existing stereotype about females being more diligent and reliable in general? Such a view may have arisen from females being more conscientious at school and doing better at both school and university. However, this finding seems to be driven solely by the business sales assistants occupation suggesting that customer discrimination against males is the explanation. Riach and Rich (2006), who conducted a field experiment in London, arrived at a similar result, namely that females are preferred not only in female-dominated occupations, but also in mixed occupations.

The analysis of what characterises workplaces that act on the name of the applicant shows that the sex of the recruiter at the workplace and the fraction of males at the firm have basically no influence upon the difference in callback rate. In other words, no obvious link between sex composition and discrimination exists at the firm level either. This result might be expected with the small differences in treatment found at the occupational level in mind. However, there is some surprising evidence that male recruiters in male-dominated occupations prefer female candidates (see Models 1 and 2 in Table 4) and that females' chances increase relative to males' chances with the share of males in female-dominated occupations (see Models 5 and 6 in Table 4).

These findings should rule out the presence of preference-based discrimination. For instance, if the Beckerian type of employer discrimination is present, it is expected that females' chances are lower, not higher or unaffected, if a male is responsible for recruitment as opposed to a female. Further, if preference-based employee discrimination exists, the probability for females to be invited to interview is expected to diminish, not increase or be unaffected, as the share of males increases. Therefore, the differences in callback rate that are still found, in particular among female-dominated occupations, are most likely driven by 
stereotypes regarding which occupations are suitable for males and females. To some extent, among both females and males, a common idea may exist that females are more productive in female-dominated occupations.

Bagüés and Esteve-Volart (2006) arrived at a similar conclusion about the source of sex discrimination by analysing data obtained from a natural experiment in the public sector in France. They studied how the sex composition of recruitment committees affects females' chances of being offered a job. Their chance did not improve, but rather diminished, when the proportion of females in the committee increased. They also excluded preference discrimination as an explanation for females not being selected in the employment process.

The only characteristic significantly associated with the difference in callback rate is whether the firm is a public or private sector employer. Employers in the public sector treat female applicants more negatively compared to male applicants. An explanation could be that the public sector in Sweden includes heavily femaledominated, top-down organisations with a general policy to increase the share of male employees. They may then select the male applicant when choosing between a male and a female candidate with similar qualifications. From the job advertisements one can indeed see that it is not uncommon for public sector employers to explicitly state that they encourage male applicants.

\section{Conclusions}

This study is the first of its kind to use CT to measure the degree of sex discrimination in the Swedish labour market and its link to sex segregation. We found very weak support for discrimination as an important factor in explaining segregation. In male-dominated occupations there is no evidence of male and female applicants having different probability of being invited to an interview. In femaledominated occupations, even though males have a four percentage point lower probability of being invited to interview compared to females, this difference can only explain a minor part of the substantial segregation prevailing in these occupations. The conclusion is that, in general segregation is not a result of present discrimination but rather determined by labour supply, that is, by females' and 
males' choice of education and occupation. If it is desirable to achieve a more integrated labour market, anti-segregation measures have to focus on the supply side. The only exception seems to be the restaurant workers occupation where the level of discrimination found in the experiment is able to explain existing segregation.

However, it is important to mention that a false expectation of future discrimination when entering the labour market can still influence the supply side and the choice of profession. Discrimination in the past may also have contributed to today's segregated labour market.

Even though the differences in callback rate between males and females at the sector level are small, there is still variation at the firm level in how the applicants are treated. The analysis of this variation revealed two interesting findings. First, at the firm level, neither the sex composition of employees nor the sex of the recruiter influence the difference in male and female applicants' chances of being invited to interview. This suggests that, among female-dominated occupations where females had a somewhat higher callback rate, preference-based discrimination should be rejected as the explanation. Discrimination is rather driven by stereotypes common to both males and females.

Second, compared to private sector employers, public sector employers were found to be more likely to invite male applicants to interview than females. An explanation of this can be that the public sector, which is heavily female-dominated in Sweden, is pushing to increase the share of males in the sector.

Future studies should investigate the existence of sex discrimination in the appointment of managerial jobs in which sex discrimination is often assumed to exist. 


\section{References:}

Allosino, E., Reyneri, E., Venturini, A. and Zincone, G. (2004) "Labour market discrimination against migrant workers in Italy", International Migration Papers 67, Geneva, International Labour Office.

Altonji J, Blank R (1999) Race and Sex in the Labor Market. In Ashenfelter O, Card D (ed) Handbook of Labor Economics. Elsevier. Amsterdam 3143-3259.

Arrow, K.J. (1973). "Theory of Discrimination." In Ashenfelter and Rees, editors, discrimination in Labor Markets.

Bagüés, M. and Esteve-Volart, B. (2006) "Will Sex Parity Break the Glass Ceiling? Evidence from a Randomized Experiment.", Presentation på EALE konferens, Prag, Tjeckien

Becker G (1957), "The Economics of Discrimination”, University of Chicago Press, Chicago.

Carlsson, M. and Rooth, D-O (2007), "Evidence of ethnic discrimination in the Swedish labor market using experimental data", Labour Economics, Vol. 14, Issue 4, p. $716-729$

Edin, P-A. and Lagerström, J. (2006), Blind Dates: Quasi-experimental Evidence on Discrimination, Working Paper 2006:4, IFAU, Uppsala.

Edin, P-A and Richardson, K. 2002. "Swimming with the tide: solidarity wage policy and the sex earnings gap". Scandinavian Journal of Economics, Vol. 104 (1), 48-67.

England, P. (2005) "Sex inequality in labour markets: the role of motherhood and segregation" Social Politics, Summer, 264-288.

Ekberg, J. \& Rooth, D-O. [2004], Yrke och utbildning på 2000-talets arbetsmarknad - skillnader mellan inrikes och utrikes födda personer, Bilaga till Rapport Integration 2003, Integrationsverket.

Heckman, J. (1998), "Detecting discrimination", Journal of Economic Perspectives, vol. 12 , pp 101-16

Johansson, Mats and Katz, Katarina and Nyman, Håkan. (2005), "Wage Differentials and Sex Discrimination. Changes in Sweden 1981-98" , Acta Sociologica , pp. pp. 341-364.

Le Grand C (1992) "Explaining the Male-Female Wage Gap: Job Segregation and Solidarity Wage Bargaining in Sweden", Acta Sociologica 34, 261-278. 
Le Grand, Carl (1997) "Kön, lön och yrke - yrkessegregering och lönediskriminering mot kvinnor i Sverige" i Persson, Inga \& Wadensjö, Eskil: SOU 1997: 136 Kvinnors och mäns löner - varför så olika? Stockholm: Fritzes

Å. Löfström, "En könssegregerad arbetsmarknad - hinder för fria val och effektiv matchning?", Könssegregeringens olika dimensioner", Ekonomisk Debatt, 2005, no 8.

Meyersson-Milgrom, E., Petersen, T. and Snartland, V. (2001) "Equal Pay for Equal Work? Evidence from Sweden and a Comparison with Norway and the U.S." Scandinavian Journal of Economics, Vol 103, No 4, Sid 559-584

Neumark, D. with the assistance of R. Bank and K. Van Nort (1996). "Sex Discrimination in Restaurant Hiring: An Audit Study”, Quarterly Journal of Economics, 111, 915-941.

Olli Segendorf, A. and Rooth, D. (2006) "Wage Effects of Search Methods for Immigrants and Natives - the Case of Sweden", mimeo, Högskolan i Kalmar.

Palme, M. \& Wright, R. E., 1992, "Sex discrimination and compensating differentials in Sweden", Applied Economics, Vol. 24, sid. 751-759.

Phelps, E. (1972), "The Statistical Theory of Racism and Sexism", American Economic Review, vol. 62, pp. 659-61

Polachek, S. (1981) 'Occupational Self-Selection: A Human Capital Approach to Sex Differences in Occupational Structure', Review of Economics and Statistics 58: 6069.

Polachek, Solomon William. 1985. "Occupation Segregation: A Defense of Human Capital Predictions." Journal of Human Resources 20(3):437-440.

Riach, P. and J. Rich (1987). "Testing for Sexual Discrimination Market", Australian Economic Papers 26, 165 - 178.

Riach, P. A. and Rich, J. (2002), "Field experiments of discrimination in the market place", The Economic Journal, Vol. 112, F480-F518

Riach, P. A. and Rich, J. (2006), "An Experimental Investigation of Sexual Discrimination in Hiring in the English Labor Market", Advances in Economic Analysis \& Policy, Vol. 6 [2006], No. 2, Article 1

Robinson, J. (1933) “The economics of imperfect competition”, MacMillan, London

Statistics Sweden (2006), http://www.scb.se/

Labour Forces Survey (2006), Statistics Sweden, http://www.scb.se/ 
Weichselbaumer, D. (2004). "Is it Sex or Personality? The Impact of Sex- Stereotypes on Discrimination in Applicant Selection”, Eastern Economic Journal 30, 159-86. 


\section{Appendix A}

Table A1. Difference in callback rate, share of females, and skill requirement

\begin{tabular}{|c|c|c|c|}
\hline Occupation & $\begin{array}{c}\text { Difference in callback rate } \\
\text { Male vs. Female }\end{array}$ & $\begin{array}{c}\text { Share } \\
\text { of females } \\
(\%)\end{array}$ & $\begin{array}{c}\text { Classification of } \\
\text { occupations }\end{array}$ \\
\hline Construction workers & 0.10 & 1 & 2 \\
\hline Motor-vehicle drivers & 0.03 & 7 & 2 \\
\hline Nurses & 0.04 & 91 & 3 \\
\hline Upper secondary school teachers & 0.03 & 53 & 3 \\
\hline Lower secondary school teachers (math and science) & 0.02 & 76 & 3 \\
\hline Shop sales assistants & 0.00 & 76 & 2 \\
\hline Lower secondary school teachers (language) & 0.00 & 66 & 3 \\
\hline Computer professionals & -0.01 & 24 & 3 \\
\hline Preschool teachers & -0.06 & 92 & 3 \\
\hline Business sales assistants & -0.06 & 38 & 2 \\
\hline Cleaners & -0.03 & 80 & 1 \\
\hline Accountants & -0.08 & 75 & 3 \\
\hline Restaurant workers & -0.11 & 68 & 1 \\
\hline
\end{tabular}

Notes: This table reports the difference in callback rate between males and females for each occupation together with the share of females in the occupation according to Statistics Sweden (2006) and the classification of the occupations according to a simplification of Swedish Standard Classification of Occupations, Statistics Sweden. The Pearson Correlation Coefficient is -0.45 (and insignificant) between the difference in callback rate and the share of females in the occupation. The correlation between the difference in callback rate and the classification is 0.25 and insignificant. 
Table A2. Descriptive statistics over firm characteristics

\begin{tabular}{|c|c|c|c|c|c|}
\hline Variable & $\begin{array}{c}\text { Only male } \\
\text { invited }\end{array}$ & $\begin{array}{c}\text { Only female } \\
\text { invited }\end{array}$ & $\begin{array}{c}\text { Both } \\
\text { invited }\end{array}$ & $\begin{array}{l}\text { None } \\
\text { invited }\end{array}$ & Total \\
\hline \multicolumn{6}{|l|}{ Recruiter information } \\
\hline Male responsible & 0.561 & 0.578 & 0.418 & 0.589 & 0.550 \\
\hline \multicolumn{6}{|l|}{ Composition of employees } \\
\hline Males $^{\dagger}$ & $\begin{array}{c}0.475 \\
{[0.291]}\end{array}$ & $\begin{array}{c}0.502 \\
{[0.304]}\end{array}$ & $\begin{array}{c}0.389 \\
{[0.291]}\end{array}$ & $\begin{array}{c}0.502 \\
{[0.297]}\end{array}$ & $\begin{array}{c}0.476 \\
{[0.299]}\end{array}$ \\
\hline \multicolumn{6}{|l|}{ Workplace characteristics } \\
\hline Employees : 0-19 & 0.588 & 0.609 & 0.511 & 0.582 & 0.571 \\
\hline Public sector & 0.254 & 0.106 & 0.338 & 0.141 & 0.187 \\
\hline \multicolumn{6}{|l|}{ Occupation fixed effects } \\
\hline Computer professionals & 0.061 & 0.062 & 0.042 & 0.077 & 0.067 \\
\hline Motor-vehicle drivers & 0.061 & 0.037 & 0.032 & 0.054 & 0.048 \\
\hline Construction & 0.070 & 0.025 & 0.026 & 0.043 & 0.039 \\
\hline Business sales assistants & 0.184 & 0.255 & 0.209 & 0.137 & 0.168 \\
\hline Lower secondary school teachers (language) & 0.053 & 0.043 & 0.064 & 0.026 & 0.038 \\
\hline Teachers upper secondary school & 0.079 & 0.043 & 0.035 & 0.036 & 0.040 \\
\hline Restaurant & 0.026 & 0.106 & 0.026 & 0.111 & 0.086 \\
\hline Accountants & 0.061 & 0.118 & 0.051 & 0.147 & 0.117 \\
\hline Cleaners & 0.009 & 0.019 & 0.010 & 0.057 & 0.039 \\
\hline Preschool Teachers & 0.140 & 0.155 & 0.289 & 0.047 & 0.116 \\
\hline Shop Sales & 0.123 & 0.087 & 0.039 & 0.156 & 0.121 \\
\hline Lower secondary school teachers (math and science) & 0.044 & 0.025 & 0.055 & 0.014 & 0.026 \\
\hline Nurses & 0.088 & 0.025 & 0.122 & 0.095 & 0.093 \\
\hline \multicolumn{6}{|l|}{ Firm size fixed effects } \\
\hline Employees : 0-9† & 0.272 & 0.373 & 0.283 & 0.384 & 0.353 \\
\hline Employees : $10-99 \dagger$ & 0.342 & 0.385 & 0.257 & 0.322 & 0.317 \\
\hline Employees : $100-\dagger$ & 0.386 & 0.242 & 0.460 & 0.294 & 0.330 \\
\hline Number of workplaces & $\begin{array}{c}42.92 \\
{[84.62]}\end{array}$ & $\begin{array}{c}75.99 \\
{[271.58]}\end{array}$ & $\begin{array}{c}163.37 \\
{[355.73]}\end{array}$ & $\begin{array}{c}70.58 \\
{[273.81]}\end{array}$ & $\begin{array}{c}88.32 \\
{[256.67]}\end{array}$ \\
\hline$N$ & 114 & 161 & 311 & 912 & 1498 \\
\hline
\end{tabular}

Notes: This table reports the mean characteristics for the firms identified in the registers $(\mathrm{N}=1498)$ showing the characteristics for firms that invited 1) only the male applicant, 2) only the female applicant, 3) both applicants and 4) none of the applicants. All variables are measured at the work place level accept those marked with $(\dagger)$ which are at the firm level. For continuous variables standard deviations are reported in parenthesis. 
Table A3. Description of variables

\begin{tabular}{ll} 
Variable & Description \\
\hline Male responsible & Equals one if a male is responsible for recruitment at workplace, else zero \\
Males & Share of males at the firm \\
Employees : 0-19 & Equals one if the number of employees at workplace is between zero and nineteen, \\
& else zero \\
Public sector & Equals one if workplace operates in the public sector, else zero \\
Occupational fixed effects & Dummy variables assigned to one if the workplace belongs to the particular \\
& occupation, else zero \\
Firm size fixed effects & Control for number of workplaces at firm and dummy variables controlling for \\
& whether the firm has 0-9, 10-99 or more than 100 employees
\end{tabular}

Notes: This table describes the variables included in the empirical analysis of what characterize firms treating the applicants differently. 


\section{Appendix B}

Example Application A (own translation of application for computer professionals).

\section{Letter of App lication}

Hello,

My name is Erik Andersson and I am 29 years old and very interested in the advertised job. I have about five years of work experience as a computer engineer, both of maintenance and as a developer in small, medium and large projects at the company TietoEnator. My tasks have been to process data using MS SQL and Visual Basic. NET. Besides that, I have also worked with more Web oriented tasks in other projects and thereby acquired great experience of $J 2 \mathrm{EE}$, Applets, JSP, JDEC, XML and HTML etc. To some extent programming has also been conducted in the programming language $\mathrm{C}++$. In the projects I have participated I have gained experience from documentation, testing and installation as well. In addition, I am very used to have a lot of customer contact.

My education consists of a Master of Science degree from Stockholm University in engineering with specialization in information technology.

I would describe myself as a very reliable and positive thinking person. I am very patient and I have at all times control of my tasks. I always feel great

responsibility for whatever kind of job task I am performing at the moment. In my leisure time I like to go for a picnic or spend time with friends and my other half.

I look forward to an interview.

Regards,

Erik Andersson
Background (evidence of grades and references available on demand)

\section{Education}

\section{Stock holm University}

Level:

Time period:

Description:

Eniversity

Engineer

1995 - 1999

Master of Science in Engineering with specialization in

information technology

\section{Andreasgymnasiet, Stockholm}

Level:

Secondary School

Area:

Natural Science

$1992-1995$

Description: 3-year Natural Science Line

\section{Employments}

\section{Computer Specialist}

Employer:

Time period:

Description:

TietoEnator

Software development/Databases/Web

\section{Other}

\section{Shops Sales Assistant}

Employer:

Time period:

Description:

Enon Bröd

1997-04-01 - 1999-07-20

Part time during studies, selling in a bakeshop

\section{Computer Stills}

MS SQL, VB.NET, J2EE, Applets, JSP, JDBC, XML, HTML, C++, UNIX, Linur, Windows, Microsoft Visual Studio, Microsoft Net, Mattab.

\section{Language}

Swedish - Fluent

English - Fluent

Drivinglicense - B

\section{Adress:}

Erik Andersson

Clo Grass

Fastlagsv. 15

12648 HAGERSTEN

Tel: 08-681 0608

Email: erik.andersson(0hotmail.com 
Example Application B (own translation of application for computer professionals).

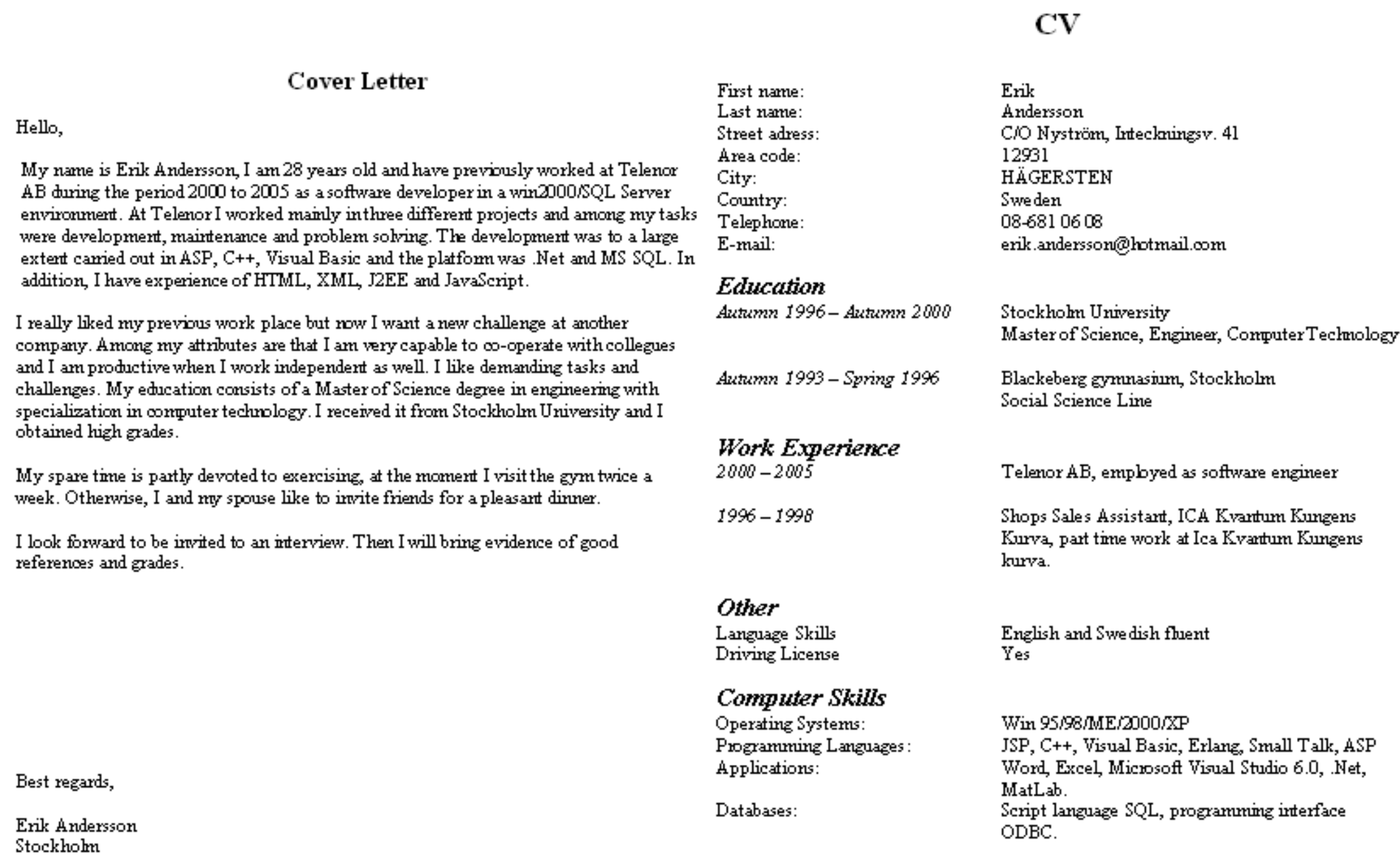


Example Application C (own translation of application for computer professionals). Regarding the advertised job opening

Hello,

First of all I would like to introduce myself. My name is Erik Andersson, I am 28 year old and I live in the city of Stockholm.

Prevously I have been employed at EssNet AB for about five years. The job assignments at EssNet were to design, implement and also test different kinds of financial applications. Most programming was done in Java J2EE environment. However, a substantial part of the developing was also conducted in $\mathrm{C}, \mathrm{C}++$ and Visual Basic .Net. Periodically I was also involved in more web-oriented projects linked to databases. That gave me experience of tools like ASP, JSP and MS SQL among others.

In person, I usually feel great job satisfaction and I never leave a project half finished. I am used to work independently and I take own initiatives to solve tasks. At my previous workplace I obtained a great experience to $\infty$-operate as well that required listen to co-workers wishes and needs to attain the desired results.

Regarding my educational attainments, I have a Master of Science degree in engineering with specialization in computer systems obtained from Uppsala University

Since I am a social-minded person I spend most of my spare time together with my girlfriend and my friends. To travel and see new places of the world is one of my interests.

I hope I will have the opportunity to come and visit you for an interview and tell more about myself and show you my excellent grades and references.

Best regards,

Erik Andersson

CiO Persson

Răsundavägen 103, 3rd floor

16950 Solna

Telephone: 08-6810508

Email: erik.andersson $\underline{0}$ hotmail.com

\section{List of Qualific ations}

\section{Education}

Uppsala University

$1995-2000$

Master of Science in Engineering

with specialization in computer systems

Sercondary Schooling

Linnéskolan Uppsala

Hatural Science Line

\section{Employments}

Computer Software Enginer $\quad 2000-2005$

Essiet AB,

Postman

Posten Uppsala, part time during studies

$1997-2000$

\section{Computer Skills}

SQL, ODBC, UHIX, Win 2000 and XP, Java, C++, C, Visual Basic, ASP, Microsoft Visual Studio and .Het, , EViews, MatLab.

\section{Other skills/experiences:}

Driving license B obtamed 1996

Language: Swedish and English 
Tables:

Table 1. Previous studies

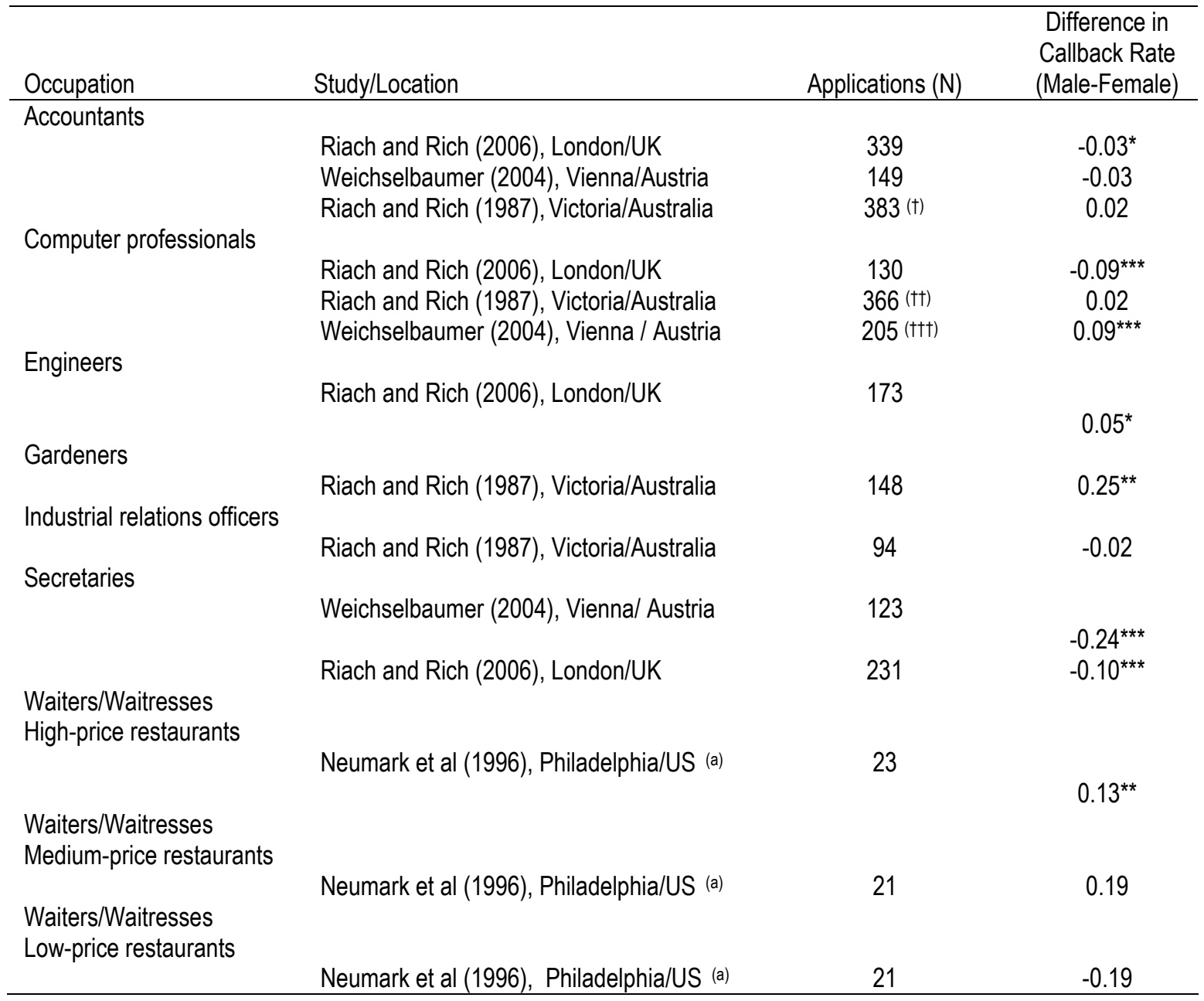

Notes: This table reports results from previous studies using the CT method. The null hypothesis tested (last column) is "Both individuals are treated unfavourably equally often". The critical value of the $\chi^{2}$ at the one percent level of significance is $6.63(* * *)$, at the five percent level of significance is $3.84(* *)$ and at the ten percent level of significance is $2.71(*)$. $(\dagger)$ The sum of management accountants and payroll clerks. (†) The sum of computer analyst programmers, computer operators and computer programmers. ( + ti) The sum of network technicians and computer programmers. (a) Neumark et al (1996) use blind applications (no job ads). Discrimination at the job offer stage is not reported in this table since the stage is not included in this study, see instead Neumark et al. (1996). 
Table 2. Descriptive results

\begin{tabular}{|c|c|c|c|c|c|c|c|c|c|}
\hline \multirow[b]{2}{*}{ Occupation } & \multirow[b]{2}{*}{$\begin{array}{l}\text { Jobs } \\
\text { No. } \\
{[1]}\end{array}$} & \multirow[b]{2}{*}{$\begin{array}{l}\text { None } \\
\text { Invited } \\
\text { No. } \\
{[2[}\end{array}$} & \multirow[b]{2}{*}{$\begin{array}{c}\text { At least } \\
\text { one invited } \\
\text { No. } \\
{[3]}\end{array}$} & \multirow[b]{2}{*}{$\begin{array}{c}\text { Both } \\
\text { Invited } \\
\text { No. } \\
{[4]}\end{array}$} & \multirow[b]{2}{*}{$\begin{array}{c}\text { Only male } \\
\text { Invited } \\
\text { No. } \\
{[5]}\end{array}$} & \multirow[b]{2}{*}{$\begin{array}{c}\text { Only female } \\
\text { Invited } \\
\text { No. } \\
{[6]}\end{array}$} & \multicolumn{3}{|c|}{ Callback rate } \\
\hline & & & & & & & $\begin{array}{c}\text { Male } \\
(5+4) /(1) \\
{[7]}\end{array}$ & $\begin{array}{c}\text { Female } \\
(6+4) /(1) \\
{[8]}\end{array}$ & $\begin{array}{l}\text { Difference } \\
\quad(7-8) \\
{[9]}\end{array}$ \\
\hline Aggregated results & 1614 & 982 & 632 & 336 & 125 & 171 & 0.29 & 0.31 & -0.02 \\
\hline Male-dominated (a) & 248 & 167 & 81 & 33 & 28 & 20 & 0.25 & 0.21 & 0.04 \\
\hline Computer professionals & 106 & 73 & 33 & 14 & 9 & 10 & 0.22 & 0.23 & -0.01 \\
\hline Motor-vehicle drivers & 78 & 53 & 25 & 10 & 9 & 6 & 0.24 & 0.21 & 0.03 \\
\hline Construction workers & 64 & 41 & 23 & 9 & 10 & 4 & 0.30 & 0.20 & 0.10 \\
\hline Mixed (b) & 402 & 201 & 201 & 106 & 39 & 56 & 0.36 & 0.40 & -0.04 \\
\hline Business sales assistants & 278 & 140 & 138 & 73 & 23 & 42 & 0.35 & 0.41 & -0.06 \\
\hline Lower secondary school teachers (language) & 60 & 25 & 35 & 21 & 7 & 7 & 0.47 & 0.47 & 0.00 \\
\hline Upper secondary school teachers & 64 & 36 & 28 & 12 & 9 & 7 & 0.33 & 0.30 & 0.03 \\
\hline Female-dominated (c) & 964 & 614 & 350 & 197 & 58 & 95 & 0.26 & 0.30 & -0.04 \\
\hline Restaurant workers & 140 & 110 & 30 & 8 & 3 & 19 & 0.08 & 0.19 & -0.11 \\
\hline Accountants & 186 & 140 & 46 & 17 & 7 & 22 & 0.13 & 0.21 & -0.08 \\
\hline Cleaners & 62 & 54 & 8 & 4 & 1 & 3 & 0.08 & 0.11 & -0.03 \\
\hline Preschool teachers & 184 & 45 & 139 & 96 & 16 & 27 & 0.61 & 0.67 & -0.06 \\
\hline Shop sales assistants & 200 & 156 & 44 & 14 & 15 & 15 & 0.15 & 0.15 & 0.00 \\
\hline Lower secondary school teachers (math and science) & 42 & 14 & 28 & 19 & 5 & 4 & 0.57 & 0.55 & 0.02 \\
\hline Nurses & 150 & 95 & 55 & 39 & 11 & 5 & 0.33 & 0.29 & 0.04 \\
\hline
\end{tabular}

Notes: This table reports descriptive results of the experiment. (a) All occupations where the share of females is lower than $2 / 3$ (b) All occupations where the share of females is between $1 / 3$ and $2 / 3$ (c) All occupations where the share of females is greater than $1 / 3$. The share of females in each occupation is taken from Statistics Sweden (2006). 
Table 3. The probability of callback for interview.

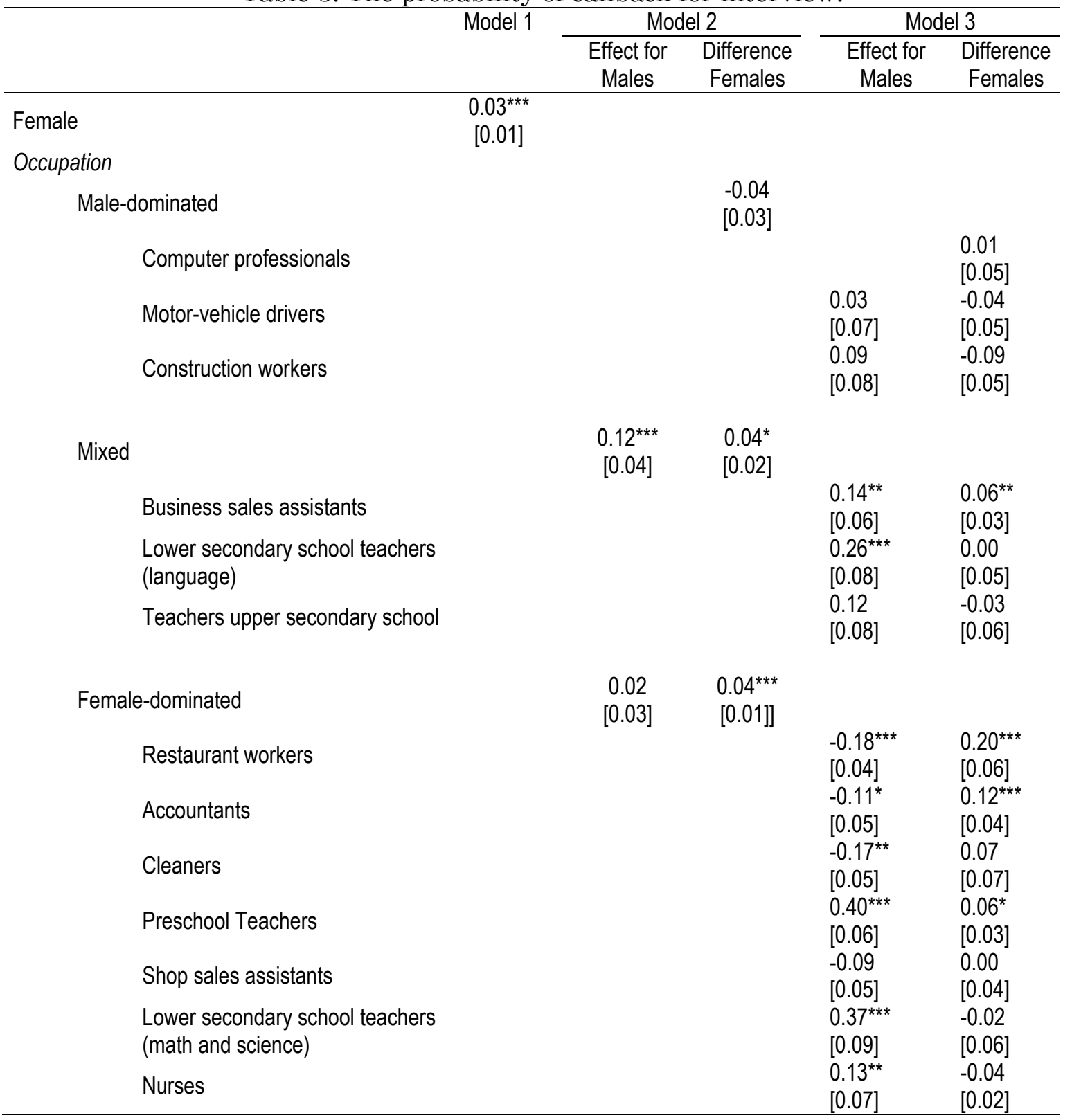

Notes: This table reports effects from discrete changes in the independent variables on the probability of being invited for interview using probit regressions with the number of observations being 3,228. Column 1 reports the average effect on the probability of being a female applicant compared to a male applicant. Model 2 reports the effects on the probability of applying in the categories mixed and femaledominated occupations compared to in male-dominated occupations. The category variables are also interacted with the female dummy to reveal any differences between males and females within the categories. Model 3 reports corresponding effects as Model 2 but on the occupational level. *, **, and *** denote the ten, five and one percent significance level, respectively. Reported standard errors (in brackets) are adjusted for clustering on workplace. 
Table 4. Factors influencing difference in callback rate.

\begin{tabular}{|c|c|c|c|c|c|c|}
\hline & \multicolumn{2}{|c|}{$\begin{array}{c}\text { Male } \\
\text { dominated } \\
\text { occupations }\end{array}$} & \multicolumn{2}{|c|}{$\begin{array}{c}\text { Mixed } \\
\text { occupations }\end{array}$} & \multicolumn{2}{|c|}{$\begin{array}{c}\text { Female } \\
\text { dominated } \\
\text { occupations }\end{array}$} \\
\hline & 1 & 2 & 3 & 4 & 5 & 6 \\
\hline Male responsible & $\begin{array}{c}0.09 \\
{[0.07]}\end{array}$ & $\begin{array}{l}0.13^{*} \\
{[0.07]}\end{array}$ & $\begin{array}{c}0.08 \\
{[0.06]}\end{array}$ & $\begin{array}{c}0.03 \\
{[0.07]}\end{array}$ & $\begin{array}{c}-0.04 \\
{[0.03]}\end{array}$ & $\begin{array}{c}-0.04 \\
{[0.03]}\end{array}$ \\
\hline Males & $\begin{array}{l}-0.08 \\
{[0.08]}\end{array}$ & $\begin{array}{c}0.01 \\
{[0.12]}\end{array}$ & $\begin{array}{c}0.08 \\
{[0.08]}\end{array}$ & $\begin{array}{l}-0.11 \\
{[0.10]}\end{array}$ & $\begin{array}{c}0.16^{* * *} \\
{[0.06]}\end{array}$ & $\begin{array}{c}0.13 \\
{[0.09]}\end{array}$ \\
\hline Employees : 0-19 & $\begin{array}{l}-0.01 \\
{[0.05]}\end{array}$ & $\begin{array}{c}0.01 \\
{[0.10]}\end{array}$ & $\begin{array}{l}-0.08 \\
{[0.06]}\end{array}$ & $\begin{array}{l}-0.23^{* *} \\
{[0.08]}\end{array}$ & $\begin{array}{c}0.02 \\
{[0.03]}\end{array}$ & $\begin{array}{l}-0.03 \\
{[0.04]}\end{array}$ \\
\hline Public sector & $\begin{array}{l}-0.17 \\
{[0.08]}\end{array}$ & $\begin{array}{c}-0.18 \\
{[0.08]}\end{array}$ & $\begin{array}{l}-0.11^{\text {** }} \\
{[0.05]}\end{array}$ & $\begin{array}{l}-0.16 \\
{[0.13]}\end{array}$ & $\begin{array}{c}-0.06^{* *} \\
{[0.02]}\end{array}$ & $\begin{array}{l}-0.12^{\star \star} \\
{[0.05]}\end{array}$ \\
\hline Occupational fixed effects & No & Yes & No & Yes & No & Yes \\
\hline Firm size fixed effects & No & Yes & No & Yes & No & Yes \\
\hline Number of cases & 462 & 462 & 738 & 738 & 1.796 & 1.796 \\
\hline
\end{tabular}

Notes: This table reports the interaction effects between the female dummy and different firm and workplace characteristics on the probability of being invited for interview. These are the estimated marginal changes in the probability for the continuous variables and estimated discrete changes for dummy variables *, **, and *** denote the ten, five and one percent significance level respectively. Reported standard errors (in brackets) are adjusted for clustering on workplace. 